\title{
Britishness and Canadian nationalism: Daughters of the Empire, mothers in their own homes, 1929-45
}

During the Depression and the Second World War the IODE's vision for Canada was influenced by Britain's weakening position in relation to a strengthening Canada. Although the influence of investments and popular culture from the USA was increasing at that time, British immigrants were still valued as superior to those of other races and the IODE promoted its own version of British-influenced arts and culture. Through booklets, work in schools and radio broadcasts the IODE created heritage and tradition. Largely unaware of American or French Canadian presences, the IODE continued to negotiate access to spaces where it could reinforce its own construction of a British Canadian identity. During the Second World War, when Canada came to Britain's aid, stringent organization led to a massive contribution to the war effort by large numbers of IODE women. The IODE used its maternal position to reinforce allegiance to Britain, but its perception was ever more Canada-centered. With women's increasing status in society, the IODE's war work was ever-confident and impressive. Although undertaken in a different time, it was work that was still grounded in a maternal identity which drew upon notions of female imperialism developed at the beginning of the century.

\section{Making a British Canada during the 1930s}

Soon after the Schoolgirl Tour the IODE asked the SOSBW if it could become the Society's sole Canadian representative in Canada. The situation became tense when the SOSBW turned down the request. The SOSBW condescendingly wrote to the IODE: 'We are glad that in spite of the inability of the IODE to correspond officially with the SOSBW, we may still count upon their kind help in various directions. We owe a debt of gratitude to the Order in relation to the Schoolgirls' Tour, and should greatly regret a severance of connection with such good friends. ${ }^{1}$ 
Why did the SOSBW refuse sole-agent status to the IODE? Although the IODE was clearly spectacularly competent at organizing events such as the Schoolgirl Tour, and was otherwise of great use to the SOSBW, it is important to remember that the IODE was one of many women's and immigration organizations active at the time. In declining to place its eggs in just one basket, the SOSBW hoped to draw upon groups such as the YWCA, the Salvation Army, the WCTU, the Girls' Friendly Society, the British Oversea League and the Navy League. Competition between these groups saw them vying for attention and was beneficial to the SOSBW. Further, due to hierarchies of Empire, the SOSBW displayed a mixture of condescension and wariness towards the IODE. Given the Victoria League's reticence towards the IODE, it is not surprising that the SOSBW also felt that the IODE needed to be kept in its place. Hence it continued to acknowledge the IODE's status as a 'friend', rather than recognize it as an equal. Despite the IODE's special efforts, there would be no special treatment for the Order from London.

Rejected, the IODE expressed an increasing pragmatism in its attitude towards Britain and seemed tired of trying to encourage British immigrants on idealist grounds. The 1929 transfer of the canadianization work to the immigration committee of the Order was an acknowledgement that there would have to be even more active canadianization, as well as securing British immigrants. ${ }^{2}$ When SOSBW representatives, Miss Franklin and Miss Hargreaves, visited Canada in 1930 to meet with the IODE about the immigration of educated girls and to reconsider the IODE as the Society's sole Canadian agent, the IODE was sceptical. The Order told Miss Franklin that a survey in the late 1920s for the placement of educated British women had produced disappointing results. And with more girls graduating from higher education within Canada, the Order no longer thought that large-scale interim domestic work for British immigrants would be viable. ${ }^{3}$

The IODE's cautiousness was not surprising given the onset of the Great Depression. The Depression forced radical reconsideration of Empire settlement schemes and according to Dane Kennedy effectively 'killed the grand emigration plans of Amery and Milner, the Dominions having no interest in adding to their unemployment ${ }^{\prime}{ }^{4}$ At the end of the summer of 1930, R. B. Bennett, the new Conservative Prime Minister, cut off immigration. With thousands of Canadians unemployed, the IODE grew more wary of immigrants, especially those from the British 'lower classes'. Although it was opposed to cutting immigration altogether, the IODE was suspicious that Britain was using Canada to alleviate its own domestic problems. ${ }^{5}$ When the Empire Settlement Act came up for renewal in 1937, the IODE recognized that Britain 'with its 
large number of unemployed is extremely anxious to place these people in the Dominions'. ${ }^{6}$ The IODE felt that Canada could afford to 'select prospective settlers with the greatest care' so that they 'are not to become failures or add further to the relief rolls'.

Despite such scepticism, however, in general, the IODE's preference for British immigrants and a British-based society remained unchanged. In a 1938 Vancouver radio broadcast, IODE member Mrs Hodgson stated: 'British settlers are badly needed in Canada today for its future wellbeing and in order that our British heritage and traditions may forever remain part of our national pride. It is hoped that our government will soon see its way clear to open the gates of Canada to selected settlers from the British Isles. ${ }^{8}$ A booklet prepared in 1939 titled 'Canada within Empire' shows how little, in some ways, ideas had changed since 1900. Canada's vast spaces were united not by features of their location in Canadian space, but instead through a connection to the British Empire:

$[T]$ he great distances separating the peoples of the various provinces, the lack of a national educational policy, the racial and religious differences all make it difficult to achieve a conscious national unity, but a knowledge of our common heritage within the Empire, the principles of justice and freedom, should form a basis for mutual understanding and cooperation. ${ }^{9}$

The symbols of Canadian identity to be taught to immigrants were still defined through the subjugation of difference; the symbols of the flag, the coat of arms and the monarchy were mentioned, and Great Britain was still presented as 'the mother country'. Aside from the considered five races of the English, Welsh, Scottish, Irish and French Canadians, there was a significant discounting of other ethnic groups in Canada. ${ }^{10}$ Despite promises that assimilation would permit others to participate as citizens, it was only by taking on a new identity that immigrants might belong; ultimately they were striving towards something in which they would never be able to participate fully, despite the claim of 'ideals dear to all Canadians'. ${ }^{11}$

At this time, as during the century more generally, education was an area of sustained effort by the IODE, which realized the importance of education in promoting its ideals and was quick to see the importance of textbooks and libraries for schools. Work on 'the imperial curriculum', of racial images and education in the British colonial experience, has highlighted the function of education, curriculum and textbook in 'shaping imperial images of dominance and deference'. ${ }^{12}$ Education often overlapped with canadianization, especially when the objective was to educate new Canadians in the ways of good citizenship. Such work involved English lessons in order, as the Provincial Chapter of British 
Columbia put it in 1928, to break down barriers to the 'foreigners in our midst' being instructed in 'patriotic ideals'. ${ }^{13}$ Calendars, pictures and other symbols of national and imperial attachment were constantly provided to schools by chapters across the country, a practice that has continued to the present. ${ }^{14}$ The IODE was well represented on education boards, as a contemporary Regina member recalls: 'We were on every education board in Saskatchewan, we were always invited to be on it, because we had input and we did our research and we knew what we were talking about' ${ }^{15}$

The IODE was directly influential in the classrooms thanks to the large number of teachers who were members. One such member recalls her experiences of teaching in the 1930s, and what she now perceives was a challenge to a British-influenced curriculum. Here, the connection of patriotic work in the classroom to fighting in war is strongly articulated:

Working with children in my day, you automatically taught patriotism. I don't think things were always rosy, because before I was married in 1934,1 remember one Friday afternoon everything was done and I had a bright class of boys . . . they'd call them junior high today - they were ready for high school. And I said, 'Right, now you can have a concert', and they always loved a concert and I always tried to get my children to speak on their feet; I thought it was very important for them to be able to stand up in front of people and express themselves. So they would elect a chairman and the kids had to do what the chairman told them to do - if it was to speak for three minutes on daylight saving and so on and in-between that we'd sing songs . . . we were singing 'Rule Britannia, Britannia Rules the Waves'. So there came a knock at the door, and it was the principal of the school, the first time that I'd ever seen the man, and I said, 'What do you want?' And he said, 'We're not allowed to teach those war-mongering songs any more.' This is 1934. I said, 'Oh, who says so?' He said, 'The Department of Education.' That was at the beginning of what we are now in, bilingualism and multiculturalism and so on, you know.

Four or five years later, I stood on the platform of the CPR [Canadian Pacific Railway] Station, out the back of town here, and the train was leaving for Halifax. It was a train full of soldiers, and the boys were on board and the IODE was there with our baskets, and we had kleenex (tissues) and candy and cigarettes, and things you give young people going away. And there were three or four of those boys there who had gone to school with me and [who] I knew, and they knew me, and I said to one of them (he used to caddy for me at golf, boy he was a good golfer!), I said, 'Honey, have you any idea what you're going to fight for, besides a pay cheque?' And he turned around, and he looked at me for a few minutes, and he said, They didn't give us much chance to learn, did 
they Mrs Baker?' I said, 'No, they didn't. And,' I said, 'it's just sad to be leaving that way.' And that was my one feeling that I had to that 1939 war. I blame Canadian schools for the watering down. You know, right now we take our Canadian troops and we put them off in Cyprus or we put them off in Somalia or somewhere else, and they haven't had any and I'm going to use the word - INDOCTRINATION to give them a reason why, as a Canadian, they should be there. And I think that's wrong. That's like me giving you a loaded gun and saying go kill anyone you want to. You don't have to have a reason, and I don't think it's right. $^{16}$

The 'indoctrination' referred to was the narrative of Anglo-Canada that the IODE actively promoted through education. In the 1930s education that emphasized strong attachments to the British Empire provided a precursor to participation in the Second World War.

\section{Working for victory}

Contemporary members are quick to recall the IODE's contribution to the Second World War. The belief that war was central to the IODE's identity is expressed in the recollection of a Fredericton, New Brunswick, member:

The First World War, yes, that's when the IODE really flourished, because there was a need in every field, for veterans and veterans' children, and sending things overseas and raising money to help with the overseas projects. Tag days, and everyone was so patriotic that the IODE really flourished. Of course that's why we were established in the very beginning. ${ }^{17}$

With the proximity of the war there came the accompanying sense among members that it was during war that the IODE was of 'greatest importance ${ }^{\prime 18}$ Both in sources from the time and in recent accounts, it is clear that the IODE considered its work important, an indicator of women's recognition of their work as a vital part of the war effort. As women's place in Canadian society by the Second World War was not characteristically one of meekness, neither was the IODE's war work. Yet the IODE's contribution was influenced by enduring ideological beliefs about women's place from the past.

The Second World War saw the IODE contributing to the war effort through a wide spectrum of identities and spaces. Of particular importance in the IODE's work was a complex maternal identity. On one level maternal identity was played out on the 'home front', with women making up for absent men. It was with women's blessing that 'the men who sail in little ships through treacherous waters endure with fortitude and patience the trials through which they must pass because 
of what they learned of these virtues at their mother's knee' ${ }^{19}$ From the domestic site of the home, the IODE intervened and constructed places as mothers. On a wider - metaphorical - level there was the rhetoric of 'Canada prides herself on having been on the side of the motherland and since war began has paid her way, has the largest volunteer fighting force in the World, the largest small arms factory in the Empire, and has been privileged to share in the great glories as the daughter who is mistress on her own house. ${ }^{\prime 20}$ Maternal identity was complex and replete with contradictions. Such a situation led to the IODE's presence in many different places and levels during wartime.

The IODE advanced particular constructions of motherhood in order to justify its contribution to the war effort. In Echoes in 1942 there was reference to the role of the mother in international relations:

Who has such valuable training in a kind and just diplomacy as the Mother of a family? Who so impartial when judgement is required? Who so anxious to distribute fairly the material benefits at her disposal? I beg of you mothers, carry this spirit of tolerance and understanding to every member of the human race, and we shall have new International Relationships. $^{21}$

Maternal sacrifice was construed as international in influence, representing supreme moral fortitude. As mothers, the women of the IODE occupied a domain of grief and sorrow. It was a domain that was sustained by the 'hands-on . . . useful work' of aiding the war effort. ${ }^{22}$ When such maternal identity was combined with Canadian and British identities the effect was a rousing female imperialist assertion of patriotism. An example of these identities working in combination was provided at the IODE National Meeting in 1940, where the President Mrs Horkins remarked:

The exercise of mutual tolerance is of vital importance. Many women are experiencing pangs of deep sorrow at the present time. They have had to say good-bye to either a husband, a son, a brother, a sweetheart or a nephew. They are worried and their nerves are on edge. People are likely under stress of great emotion to lose the large perspective. We should think of this before criticising too severely. Canadians have inherited a splendid past from their British ancestors and it is within our power to hand down to our descendants equality and freedom, together with selflessness, co-operation, and mutual tolerance. ${ }^{23}$

In keeping with the spirit in which the IODE was formed, her words also appealed to race and British ancestry. As 'Daughters of Empire', Canadian IODE members had a part to play in helping the women and children of Britain. Of the women of the Empire, Horkins noted in her 
speech a year later: 'Their spirit and their sacrifice in this terrible war is the wonder of the world. Every day, with unflinching courage and nearly always with a smile, they say farewell to the faces which they have loved, not long since, but have lost awhile. ${ }^{24}$ Again, mothers must make sacrifices for national and imperial victory. As Horkins contended:

The blood-stained year of 1941 has brought manifold sufferings sufferings before unknown - but the fortitude of the women has been unequalled in all the annals of history. These indeed are the times that try women's souls, but all honour to the women of England, to the women of all the united nations, so goes the toast, without their courage we should be lost. ${ }^{25}$

Canada's contribution was put in a context of loyalty to Britain and to the allies of Britain and Canada. It was not enough for women to feel the horrors of war; they must also work for victory.

The vital input of women's voluntary work was recognized by the IODE. In her book Canadian Women in the War Effort, Charlotte Whitton wrote of women's home responsibilities: 'These responsibilities had - and still have - a value, in the national economy, of millions of dollars in the "non-gainful" occupation of hundreds of thousands of Canadian homemakers whose inability so to keep the gears of home life meshing would mean the complete collapse of the home front behind all war effort in the Dominion. ${ }^{26}$ At the same time as it was linked to the nation, women's work was considered to be the most suited to household and personal service, considered by Whitton as the 'most natural and accessible area of women's effort' ${ }^{27}$ (original emphasis). Reinforcing women's place in the home was a conservative statement for Whitton to have made, herself a 'new' professional woman. Yet, Whitton recognized that IODE members' collective contribution would be through maternal work, not through the activities of a minority of professional women. Whitton was able to separate her own life story from the lives of women more generally, as she generally perceived them.

As mothers collectively, the IODE 'adopted' ships and military bases, stating that 'the authorities have found the interest taken by a civilian group in a ship and its sailors to be very beneficial to the morale of the men and now desire every ship to have a sponsor or "fairy godmother"' ${ }^{28}$ Between 1942 and 1950, 357 ships were adopted by IODE chapters. ${ }^{29}$ Items sent to the ships varied from patriotic pictures of the king and queen to coffee percolators, clothing, boxing gloves and ashtrays. ${ }^{30}$ Being fairy godmothers was a complex project for the IODE. Shipments went missing and ships put in requests for items that their 
superiors did not want them to have. Caught in the middle, IODE chapters were chided by the navy. A letter to the IODE from the navy regarding the PWSC Winnipeg inquired: 'May I ask if you are putting sweaters in the ditty bags? This is contrary to the understanding reached with the Dominion Council of the Navy League and a policy which I am satisfied is unwise. Many of the men receiving ditty bags have all the sweaters they need while other men are in great need of these sweaters. ${ }^{31}$ The softer, spoiling side of motherhood did not fit with the navy's ideals of equality.

The IODE was particularly strong in work with the navy and people working at sea. This was because the navy fell into a less clear-cut official category than the army and airforce, and as a result, received fewer provisions. Two substantial IODE projects in this area were the operation of a canteen in Halifax and a seaman's mission in Saint John, New Brunswick. A contemporary member recalls the mission, and members' efforts to entertain and provide for the seamen:

It's still on Prince William Street, and that's where the seamen would come in during the war when they were on leave or had a break from their ship; and the IODE entertained almost every night of the week during the war, with dances, and serving refreshments, coffee. For years we made socks and things that they would need on board ship, heavy mittens, socks, and we made ditty bags. ${ }^{32}$

Again, the IODE was offering maternal help to refresh and bolster seamen.

As it had been during the First World War, knitting was a significant activity of the IODE. Knitting patterns were circulated for members to follow. 'We all knitted', says a member who lived in North Bay, Ontario, during the Second World War: 'It was to send overseas. I pity who ended up wearing it: I didn't know what in the name of goodness I was doing! ${ }^{13}$ As a 'reserve army of labour' women were frequently called upon to supplement government clothing supplies. One member recalls that the coastguard and merchant marines had no government-provided uniforms: 'They weren't volunteers, but they weren't actually part of service ... [but] they did an awful lot of work getting the convoys across to England'. She helped a woman who used to make vests out of scraps of fur donated by furriers: 'I was a little girl, and we didn't have sitters in those days, and so mother dragged me along and I used to help her match the pieces of fur to make up these vests for the merchant marines, and it was great fun and we'd get different patterns. ${ }^{34}$

That kind of work took place at 182 Lowther Avenue, the Toronto national headquarters of the IODE. Figure 5.1 shows members at work 


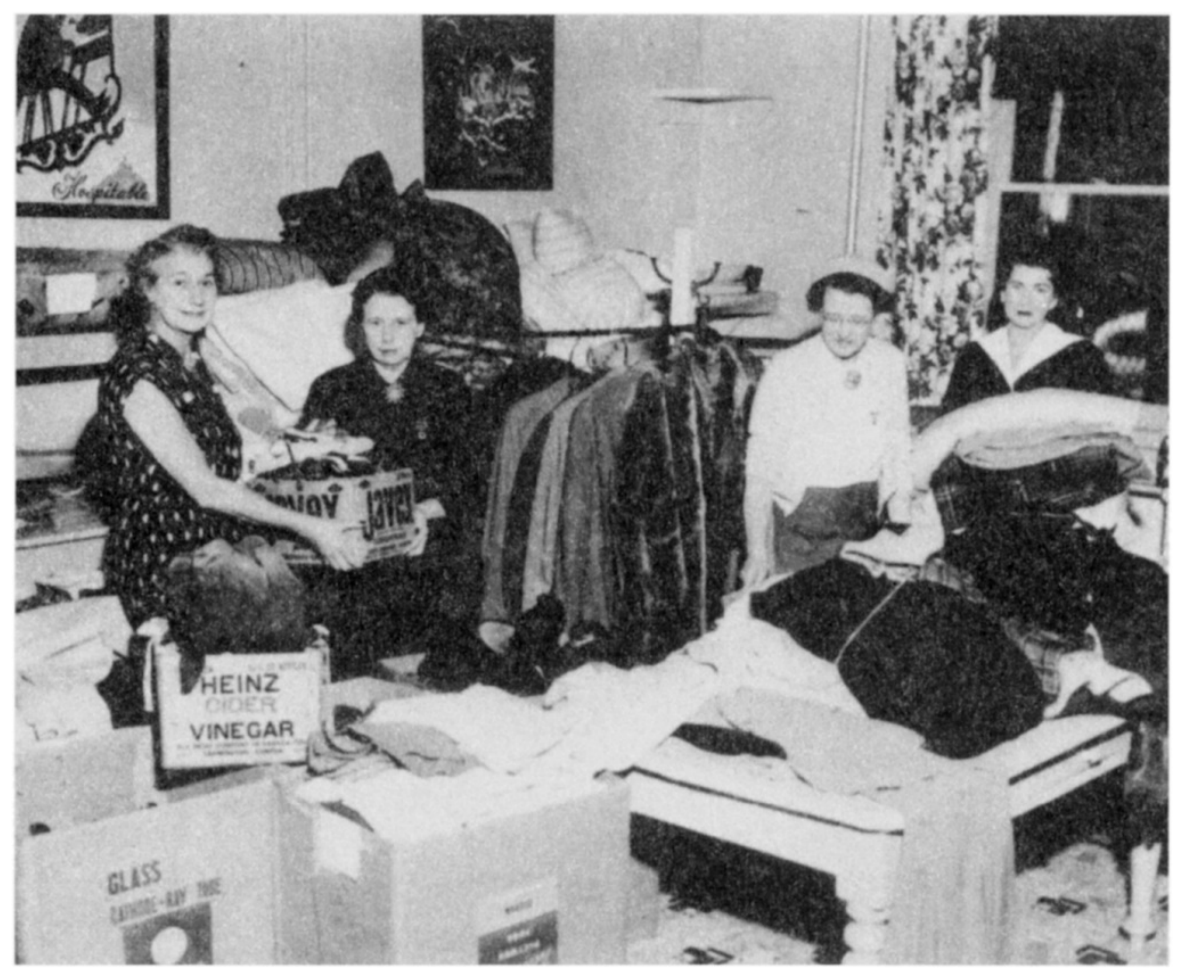

Figure 5.1 Second World War IODE members at work in the packing room at 182 Lowther Avenue

in the packing room. Recalling headquarters during the war the same member talked of making layettes to send to bombed-out families in England:

They had a stable[s] at the back and those were the working and packing rooms during the war. And it was busy practically eighteen hours a day, people packing and working. I used to carry our sewing machine on a streetcar down to this place. We lived a fair distance away, but they only had one sewing machine and if you want to get any work done you need a lot of them. ${ }^{35}$

With a lack of infrastructure and the high demand for aid, resourcefulness was essential.

Given the IODE's strong background in education and libraries, and its history of patriotism, the Department of National Defence had confidence in the IODE, and suggested that it supply books to the troops. ${ }^{36}$ The campaign for library books was regarded as a contribution to Canadian citizenship. A pamphlet produced in support of the book campaign boldly asserted: 'Books banish boredom! Books boost morale! 


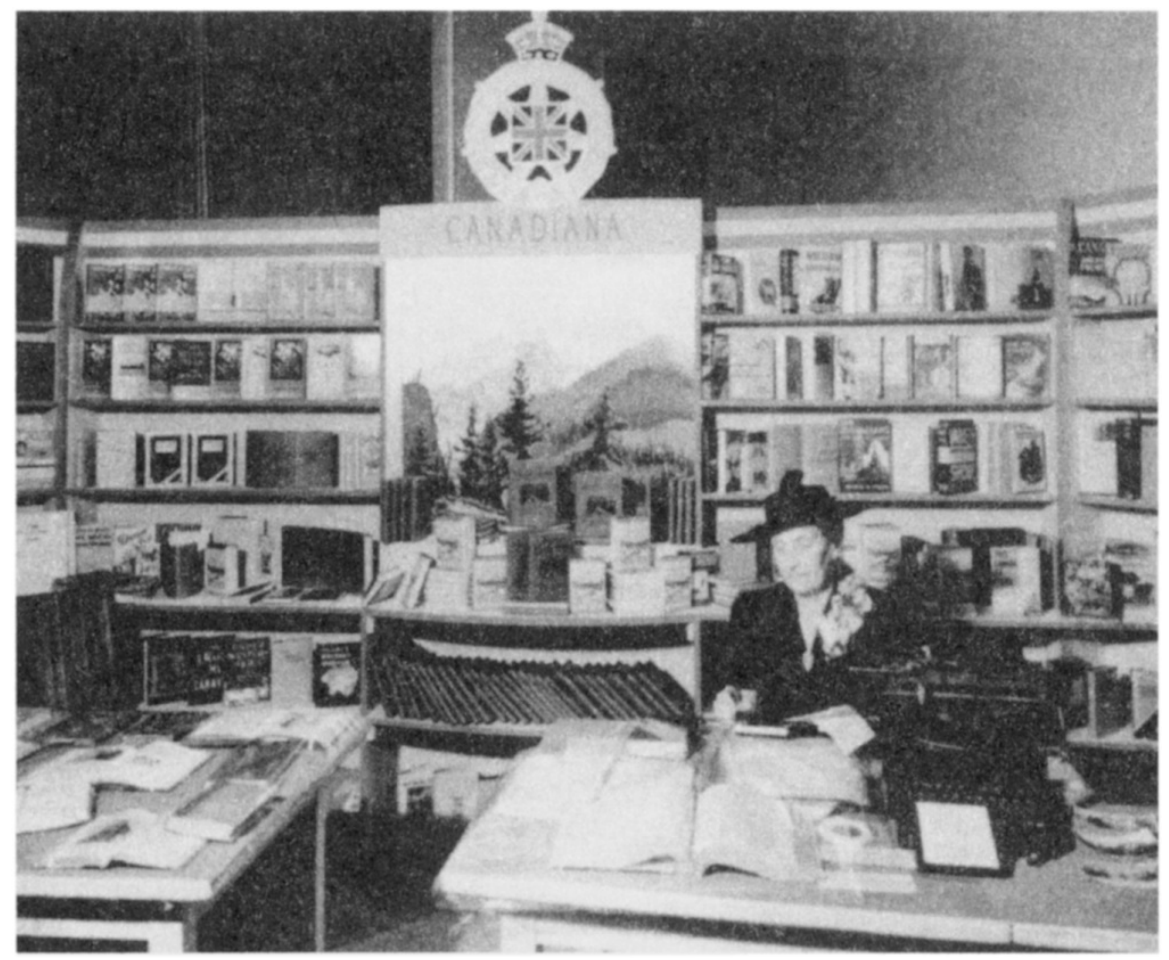

Figure 5.2 IODE Second World War service library display at the Canadian National Exhibition

Books uplift and educate! ${ }^{37}$ Building upon its roles as mothers and educators the IODE gained access to this space of citizenship formation. Figures 5.2 and 5.3 show the IODE's display at the Canadian National Exhibition in 1941, and members preparing books. The IODE attempted to control the kinds of books that should and would be read by troops, stating that 'cash is wanted as the IODE has preferred buying power and through experience knows the type of books the service people like'. ${ }^{38}$ Troops were perceived as at once defending Canada and reinforcing a sense of attachment to the Empire. Figure 5.2 features a poster that appeals to a pristine Canadian landscape, linking reading to the strong, healthy homeland. Such rousing patriotic hopes contrasted with the dirt and death of war, and with the other materials that troops read, such as information from the Canadian Communist Federation (CCF) and pornography. None the less, the IODE was well organized in this respect, and was determined to go about its work.

The IODE was just as vigorous and firm in the prosecution of its war effort in the Second World War as it had been in the First. Whereas 


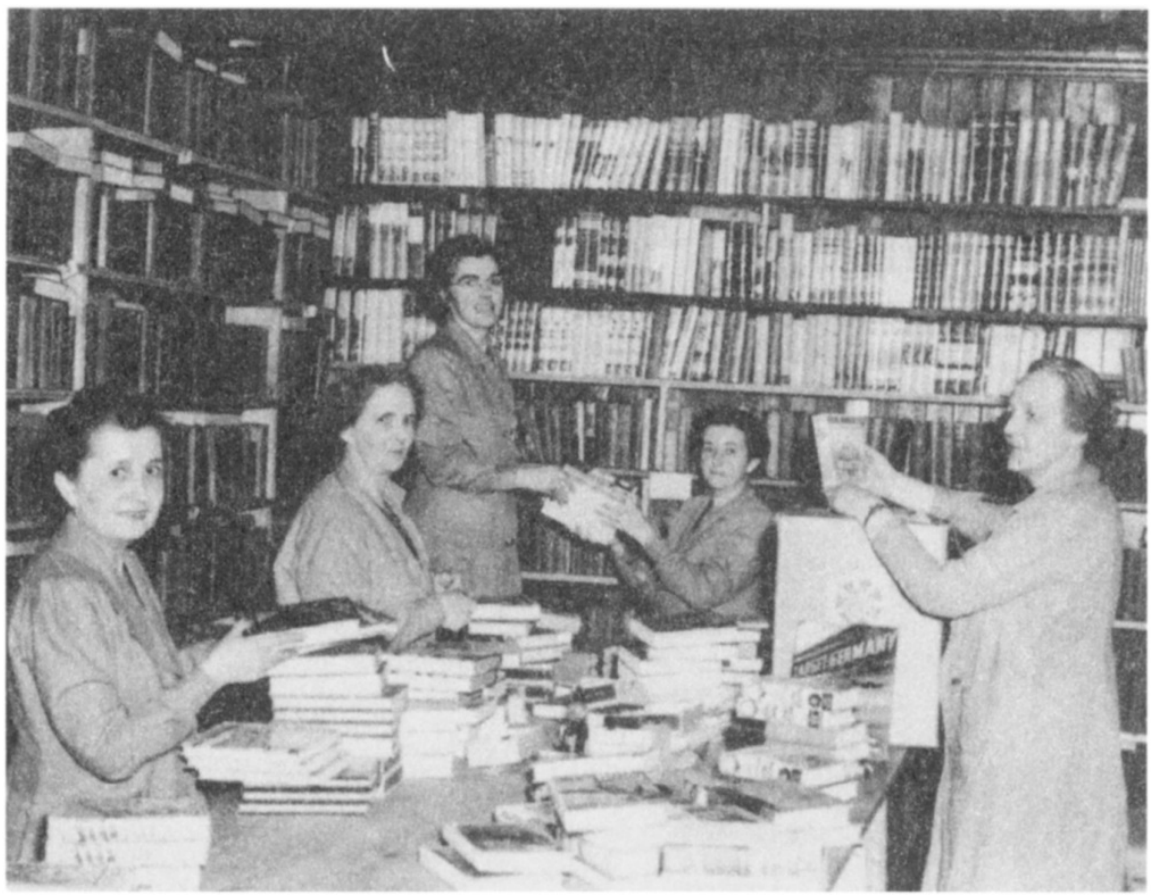

Figure 5.3 IODE Second World War service library

it began the First World War by donating a battleship, the IODE began the Second by donating a Bollingbrooke bomber. Figure 5.4 shows the bomber being presented to the Royal Canadian Airforce. In 1940 the IODE raised $\$ 100,000$ within six weeks for the Bomber Fund, and an additional $\$ 130,000$ was sent directly to the Lord Beaverbrook Aircraft Fund in England. ${ }^{39}$ Clearly, the Order's cross-Canada structure and organization, set up in the years before the First World War, were still working effectively. Sometimes provincial, municipal and local chapters initiated their own projects, while at other times, such as in the case of the Bomber Fund, there was an appeal made to all chapters by the National Chapter in Toronto.

The war accentuated the IODE's attitudes towards race. In 1942 the IODE campaigned for the forced internment of 'enemies' living within Canadian territory. At the 1942 National Meeting a motion from the Alberta Provincial Chapter was passed:

Whereas in this time of war there are enemies of the British Empire within our borders, be it resolved that a petition be sent to the government of Canada at Ottawa from the IODE petitioning them to deprive enemy aliens and subversive naturalized Canadians (who have 


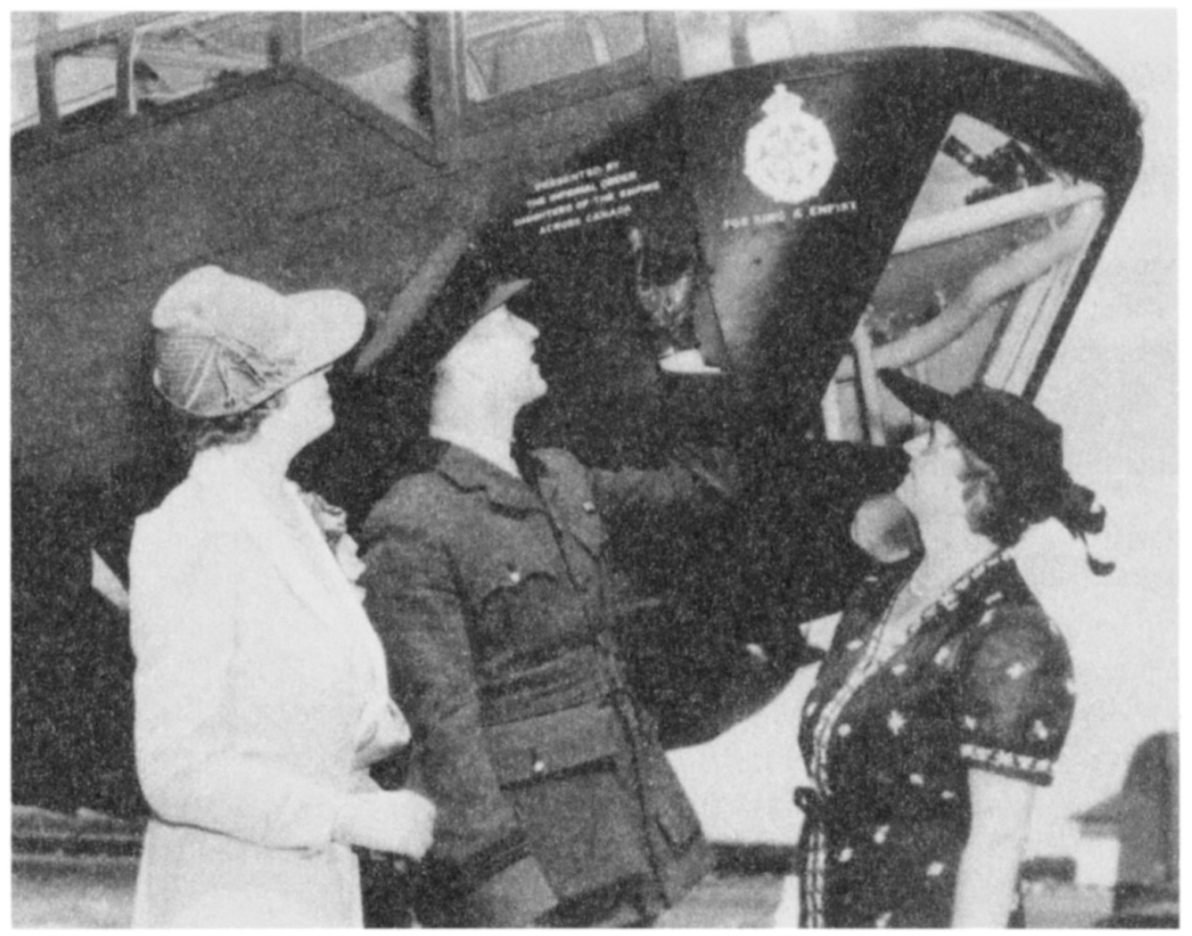

Figure 5.4 Presentation of the Bollingbroke bomber by the IODE to the RCAF

been naturalized during the past five years) of their liberty, and place them in concentration camps for the duration of the war. CARRIED. ${ }^{40}$

In the context of war, such harsh words lacked the hope of canadianization that was evident in the interwar years. Old racist attitudes surfaced in the IODE's call for internment. The British Columbia Provincial Chapter, for example, asserted in 1944 'that the dual nationality of the Japanese will never allow them to become assimilated into Canadian life' ${ }^{41}$ Individual members and local chapters varied in their sensitivity; national and provincial levels were especially rigorous. Rumoured reports of weakness towards internees made it into the national minutes. The national executive in Toronto, having been informed that on the Prairies chapters were supplying magazines and cigarettes to 'enemy aliens' in internment camps, responded: 'This action is being severely criticized by Canadians outside the Order. ${ }^{42}$ The suspension of democratic values, so important to the IODE, is understandable only in so far as the IODE deemed such action necessary to promote the goal of victory. 
The Second World War saw Canada, through its contributions to the war effort, move to a stronger position as a nation. As British cities were devastated by the bombing during the Blitz, Canada's position of strength became very apparent. As IODE President Horkins noted at the outset of the war, in 1939:

We have many things to be thankful for in Canada - our granaries are full of wheat, our sheep are grazing on the hillsides and our birds are still singing. So far there is no danger of the horrors of bombardment or the heart-rending uncertainties which confront non-combatants in war. Think of these blessings! And let us pray as we never prayed before: 'Oh God, make wars to cease! ${ }^{43}$

In this speech there was an increased awareness of Canada in and for itself, and of a Canadian environment and resources that were strong and important. Britain was still to be admired, and the courageous reaction of British citizens was used further by the IODE to glorify British identity. Later on, in 1941, Horkins noted: 'We should be proud to give as well as to lend help to those who are all "in the front line", and whose endurance and heroism compels the homage of the world. ${ }^{44}$ Britain was still the 'spearhead of modern civilization' and the 'solid bastion of democracy'. ${ }^{45}$ With this example before them, the IODE perceived a strong place for a Canadian nation to perform the duty that is 'of paramount importance to us as Canadians: it is to give our time, our money and our brains to help win this war'. ${ }^{46}$ And here women as mothers had an important part to play as Daughters of the Empire, and mothers in their own homes.

The IODE was active in helping with British war guests in Canada. The symbolic connection between Briton's homes and the Empire as a home was frequently expressed in IODE rhetoric. National War Guest Convener Edith Angas reported in 1941:

These are Britain's mothers and children who have come to us for shelter. Hitler with his bombs may destroy her homes, but he cannot destroy the love that has been fostered in those homes, nor break the ties of love which bind this Empire; he may break in pieces the lovely churches of the Motherland, but he cannot break the faith that has been nurtured in those churches, nor kill the spirit which is born of faith. ${ }^{47}$

As well as providing such temporary shelter, the IODE saw the opportunity during war to recruit 'new' Canadians considered to be eligible. Thus British women who were marrying Canadians were sent wedding dresses by IODE members. In Fredericton, New Brunswick, a member recalls: 'There weren't any wedding dresses, so IODE rounded up a number of wedding gowns in different sizes, sent them off to Britain, and loaned them to the girls so that they would be married in a 
proper dress. ${ }^{48}$ The name of the provider was fixed to the outfits 'so that the thanks of those to whom these dresses are loaned may go to the donating chapter'. ${ }^{49}$

The enthusiasm with which war brides were welcomed was reminiscent of the 1928 treatment of the English schoolgirls. These women being 'secured' were believed to be 'a fine type of English or Scotch settler whose influence will be felt all over the Dominion'. With military efficiency IODE officers urged: 'our machinery must be set up immediately, so as we may not lose the opportunity of contacting further arrivals ${ }^{\prime}{ }^{50}$ The Canadian Government also took active steps to get the war brides to Canada. This was the first time that the Canadian Government provided 'home to home' transportation for the dependants of its servicemen. ${ }^{51}$ To help the women to adapt, the IODE in 1944 produced a welcome booklet titled 'From kith to kin': 'So you will find us different, but thanks to our fine British institutions we dwell together, bounden subjects, loyal to one Crown, but Canada is proud of her full-drawn strength and rights within the household of British nations. ${ }^{52}$ Here was evidence of the identities that the IODE valued, those of mother, Canadian and British subject with membership in the big home of the British Empire.

\section{Preparing for peace}

At the end of the Second World War the IODE actively supported the return to the home of women who had been in paid employment. The IODE had supported women in the army during the Second World War, justifying its arguments by the British example. Despite the challenges war seemed to offer to patriarchy, the IODE, as representatives of the mainstream, did not intend to overturn the division of labour in Canada. As early as 1943 the IODE was corresponding with the Government's Advisory Committee on Reconstruction in developing a plan to deal with 'problems that will arise, on the conclusion of hostilities, in connection with the re-employment, readjustment and rehabilitation of women now engaged in war occupations ${ }^{\prime} .{ }^{53}$ The IODE appeared initially surprised that the sub-committee on postwar problems of women foresaw women as being so disruptive, and stated: 'it is also regrettable that the members of the sub-committee seem to take it for granted that all women (married and single) in war occupations will seek employment in the postwar period'. ${ }^{54}$ The IODE believed that women should be encouraged to return to their homes because 'the preservation of home life was of the utmost importance to the nation' ${ }^{55}$ Such opinion 
supports the argument of Ruth Roach Pierson, that wartime meant temporary practical work change for

Canadian women, and not a fundamental ideological shift in attitudes towards women and work. ${ }^{56}$

Thus the IODE continued to align itself with motherhood, a position of vital importance in its war efforts, and believed that a woman's place was in the home. Such rhetoric masked real changes in women's lives that had happened during the first half of the century. Particularly for Anglo-Celtic middle-class women, the postwar Canadian social context was very different from that of late-Victorian Canada. Their entry into higher education and the professions, and the achieving of the vote were real achievements that also contributed to a more confident position in society. After the limited federal suffrage granted to women in 1917, suffrage was extended in 1918 to each female citizen, and in 1919 women could stand for the House of Commons. Manitoba was the first province to grant women the right to vote, in 1916; and during the following years provincial women's suffrage was granted across Canada, with the last province being Quebec, in 1940. In 1929 the Person's Case declared that women were persons and so were eligible to sit in the Senate. During the interwar years, women began to enter public office. Louise McKinney was elected to the Alberta Legislature in 1917, and in 1921 Agnes MacPhail became the first woman elected to the Canadian House of Commons. ${ }^{57}$ In education, women played a prominent part, and gained a footing as professors in the universities, IODE members Wilhelmina Gordon and Mary Bollert among them. In public service and in welfare agencies, women were present as bureaucrats, the most notable IODE example being Charlotte Whitton, who would go on to become Canada's first woman mayor.

The Second World War accentuated the contradictions between feminism and patriotism. On the one hand, women proved their equality with men. During the war, once again women had shown that, in the absence of many of Canada's men, they were capable of keeping the country going, whether in the home or in gendered male occupations. Women's auxiliaries in the services nudged women toward equality in combat, and the IODE's rhetoric often displayed a strong militaristic bent. Yet, on the other hand, owing to the female imperialism that underpinned it, the IODE was able to simultaneously emphasize motherhood and women's place as 'honorary men' in strategic war matters. Such were the contradictions of being a group of women negotiating a position in a patriarchal war. Older ideas of maternal sacrifice remained at the same time as narratives of the active combat with the enemy gained strength. Meanwhile, the IODE's metaphorical conception of home as nation and Empire became, during the Second 
World War, more assertive, more confident, more proven and more Canadian in its focus. From its members' place as mistresses in the home, the IODE had negotiated access to different spaces in order to be Daughters of Empire, representing a strong, loyal Canadian identity. During the peacetime which followed, the IODE participated in powerful and innovative war memorialization.

\section{Notes}

1 NAC MG28 I 336 A-1054, SOSBW 1929 10th Annual Report, 32.

2 NAC MG28 I 17 12, 1, 6, 1930 National Meeting Minutes.

3 Ibid.

4 Dane Kennedy, 'Empire migration in post-war reconstruction: the role of the Oversea Settlement Committee, 1919-1922', Albion, 20: 3 (1988), 403-19.

5 John A. Schultz, 'Canada and Empire settlement 1918-1930', in Stephen Constantine (ed.), Emigrants and Empire: British Settlement in the Dominions Between the Wars (Manchester: Manchester University Press, 1990), 150-73, at 168.

6 Echoes, 146 (March 1937), 51: 'Only last January the British House of Commons approved a resolution which would enable the Government to contribute $75 \%$ of the cost of any migration scheme, against $50 \%$ at present.' This was a preliminary step to extend the expiring 1922 Empire Settlement Act for fifteen more years.

$7 \quad$ Ibid.

8 NAC MG28 I 17, 19, Radio scripts of broadcasts on IODE history and work for radio programme Vancouver AM, 1938.

9 NAC MG28 I 17, 40, Misc. IODE, Canada Within The Empire (Toronto: IODE, 1939), 5.

10 Ibid., 18.

11 Ibid., 5.

12 J. A. Mangan (ed.), The Imperial Curriculum: Racial Images and Education in the British Colonial Experience (London and New York: Routledge, 1993), is a collection of essays focusing on 'the function of education, curriculum and textbook in shaping imperial images of dominance and deference' (p. 1). For a discussion of Canadian textbooks, see Timothy J. Stanley, 'White supremacy and the rhetoric of educational indoctrination: a Canadian case study', in J. A. Mangan (ed.), Making Imperial Mentalities: Socialisation and British Imperialism (Manchester: Manchester University Press, 1990), 144-62.

13 BCARS N/I/IM 7P, IODE Provincial Chapter Minutes, 15 October 1928.

14 NAC MG28 I 17, 9, 6 May 1964. By 1965, the IODE calendar, started by National Education Secretary Wilhelmina Gordon, had been in existence for forty years. In 1964 the IODE printed 37,000 calendars for schools. The calendar is still produced.

15 Interview, 18 April 1994: Regina, Saskatchewan.

16 Interview, 21 October 1993: Fredericton, New Brunswick.

17 Second interview, 25 October 1993: Saint John, New Brunswick.

18 Interview, 23 October 1993: Fredericton, New Brunswick.

19 NAC MG28 I 17, 6, 11, National Meeting, presidential address by Mrs Horkins.

20 NAC MG28 I 17, 6, National Meeting, 31 May 1944.

21 'Women and international relations', Echoes, 168 (autumn 1942), 14.

22 Interview, 9 October 1993: Campbellford, Ontario.

23 NAC MG28 I 17, vol. 12, part 2, National Meeting (1940), presidential address by Mrs Horkins.

24 Ibid. 


\section{BRITISHNESS AND CANADIAN NATIONALISM}

25 NAC MG28 I 17, vol. 12, part 2, National Meeting (1941), presidential address by Mrs Horkins.

26 Charlotte Whitton, Canadian Women in the War Effort (Toronto: MacMillan, 1942), 1.

27 Ibid., 4.

28 NAC MG28 I 17, 23, 15 March 1943. Mrs Angas reports that in the records of the Department of National Defence, Naval Service, there are fifty-one ships without sponsors.

29 NAC MG28 I 17, 23, Adoption of ships 1942-50.

30 Ibid.

31 Ibid., Letter to IODE Coordinator Mrs Richardson.

32 Interview, 25 October 1993: Saint John, New Brunswick.

33 Interview, 8 November 1993: Kingston, Ontario.

34 Interview, 4 November 1993: Ottawa, Ontario.

35 Ibid.

36 Ibid.

37 NAC MG28 I 17, 23, Adoption of ships, 1942-50.

38 NAC MG28 I 17, 23, 5, Armed Services libraries campaign, 1943-45.

39 Whitton, Canadian Women in the War Effort, 31.

40 NAC MG28 I 17, 6, 30 May 1942, National Executive Minutes. The motion was from Alberta IODE.

41 NAC MG28 I 17, 6, 6 September 1944.

42 NAC MG28 I 17, 5, 3 July 1940, National Executive Minutes.

43 Mrs Horkins,'A message to the members of the Order', Echoes, 156 (autumn 1939), 3.

44 Mrs Horkins, 'How much we many owe that dauntless few', Echoes, 162 (spring 1941), 3.

45 NAC MG28 I 17, 12, 2, 11, 1940 National Meeting, presidential address by Mrs Horkins.

46 Mrs C. H. Wilson (national war service convener), 'Are we facing the facts?', Echoes, 162 (spring 1941), 5.

47 NAC MG28 I 17, 12,2, 79, 1941 National Meeting.

48 Interview, 23 October 1993: Fredericton, New Brunswick.

49 NAC MG28 I 17, 6, 6 September 1944, National Executive Minutes.

50 Echoes, 174 (February 1944), 2.

51 Ben Wicks, Promise You'll Take Care of My Daughter: The Remarkable War Brides of World War II (Don Mills, Ontario: Stoddart, 1992), 40.

52 RCSL Charlotte Whitton, From Kith to Kin (1944), 14.

53 NAC MG28 I 17, 6, 6 October 1943.

54 Ibid.

55 Ibid.

56 Ruth Roach Pierson, 'They're Still Women After AH': The Second World War and Canadian Womanhood (Toronto: McClelland \& Stewart, 1986).

57 See J. Arthur Lower, Canada: An Outline History, 2nd edn (Toronto: McGraw-Hill Ryerson, 1991 [1973]), 281-5 for a summary of the development of Canadian women's rights. Provincially, women gained the right, respectively, to vote and to be a candidate in the provinces as follows: British Columbia 1917, 1917; Alberta 1916, 1916; Saskatchewan 1916, 1916; Manitoba 1916, 1916; Ontario 1917, 1919; Quebec 1940, 1940; New Brunswick 1919, 1934; Prince Edward Island 1922, 1922; Nova Scotia 1918, 1918; Newfoundland 1925, 1925. Quebec's slowness is attributed to an extreme conservatism that was influential in social, political and religious matters during the interwar years. A History of the Vote in Canada (Ottawa: Minister of Public Works and Government Services Canada, 1997), 64-8. 